\title{
Investigating cuisine experiences in the Maldives: A novel research method utilising tasting buffets
}

\author{
Mohamed Shenaan \\ School of Hospitality and Tourism, Auckland University of Technology, New Zealand. \\ Email: mohamed.shenaan@autuni.ac.nz \\ Associate Professor Heike Schänzel \\ School of Hospitality and Tourism, Auckland University of Technology, New Zealand. \\ Email: heike.schanzel@aut.ac.nz (corresponding author)

\section{Professor Tracy Berno}

School of Hospitality and Tourism, Auckland University of Technology, New Zealand. Email tracy.berno@aut.ac.nz

\begin{abstract}
Food as a tourist activity offers the rare prospect of fulfilling all five senses, especially taste, and heightening experiences. For food studies in tourism, taking part in the act of eating and drinking as part of the research design is rare. This study aims to address this methodological gap by introducing tasting buffets as a novel research method. Buffets, which included local dishes, were arranged at three guesthouses on three different local islands in the Maldives. International tourists staying in guesthouses were recruited to sample the dishes and were then invited to participate in interviews about their experiences, perceptions, and sensory memories of food. Various themes emerged from the analysis of the interviews, including food neophilia and neophobia, food to explore local culture, indifference to food, and the connection between food, memories, and sensory recall. The study offers an effective and practical methodological contribution towards embodiment in tourism food research. It offers a valuable method to prompt discussions of local cuisines, unfamiliar cuisines, and holiday food memories, behaviours, and intentions. The efficient, practical, and useful methods utilised in this explorative study can be used as a blueprint for future food tourism studies, to explore food sensations and sensory memory recall related to food experiences.
\end{abstract}

Keywords:Food tasting; local cuisine; Maldives; sensory memory; neophilia; neophobia

\section{Introduction}

The strong connection between food and tourism (De Jong et al., 2018; Okumus, 2020; Richards, 2002) has been widely examined, highlighting the importance of cuisine and its diverse components to the tourism industry. A significant portion of tourists' budget is spent on food and drink (Berno, 2011; Disegna \& Osti, 2016; Knollenberg et al., 2021), and consuming food and drink on holiday is one of the few tourist activities that fulfils all the senses, especially taste (Goolaup et al., 2018; Kivela \& Crotts, 2006; Sutton, 2001). It has also become a significant area of focus for tourism researchers. 


\section{Copyright 2022 Cognizant Communication Corporation}

In the last few decades, academics have increasingly investigated the connection between food and tourism through various themes (De Jong et al., 2018; Lee \& Scott, 2015; Okumus, 2020), emphasising the importance of food and its components to the tourism industry. These themes include explorations of food as a travel motivator (Akyuz, 2019), food and sustainable tourism development (Berno et al., 2016, 2021; Enzenbacher, 2019), and tourists' perceptions of local food, including the link with exploring local culture (De Jong et al., 2018). The research focussed on this connection has been thorough and diverse.

Numerous methods have been employed to explore the above and other food tourism related themes. This includes predominantly quantitative surveys such as of local residents to gain understandings of their travel and cuisine intentions (Akyuz, 2019; Alderighi et al., 2016), of local food enthusiasts questioning them on their food travel inclinations (Getz \& Robinson, 2014), of tourists attending a travel fair (Björk \& Kauppinen-Räisänen, 2016), and of urban tourists visiting a large food market (Dimitrovski \& Crespi-Vallbona, 2017). Other studies focussed on supply side investigations, including surveys of destination marketing stakeholders at a tourism-marketing exhibition (Du Rand et al., 2008), and interviews and focus groups with destination and community stakeholders (Berno et al., 2021; Everett \& Aitchison, 2008). There is also a study adopting a multi-method investigation which included observations of people visiting food courts, markets, and restaurants (Enzenbacher, 2019). These explorations use a variety of methods, in various settings, focussing on a diverse assortment of participant groups.

It becomes clear that a wide array of valuable research has been conducted relating to food and tourism, with various methods utilised. However, one similarity amongst the methods used is the distance between participants and the major subject of the research - the food. With existing tourism food studies there is a detachment and disconnect between participants and the act of consuming food which are unable to fully capture the bodily senses involved, especially the sense associated with eating - taste. Taste is the most prominent factor when choosing food (Cornelis et al., 2017). Therefore, this study proclaims that it is vital that this distance is bridged, to gain a deeper understanding of tourist food experiences and food memories, through experiencing the sensations of tasting, smelling, feeling, hearing, and seeing food in situ. It thus offers the novel methodological contribution of the tasting buffet.

The aim of this study is to highlight a novel research method contribution towards participative sensory research relating to tourism and food experiences. This paper is primarily focussed on the tasting buffet method utilised to explore food tourism experiences of the participants. Although some of the findings of the study are analysed to demonstrate the potential outcomes of utilising such methods, the emphasis of this paper is on the details of how the research was conducted, specifically focussed on what the authors contend, is an innovative method of food tourism research.

\section{Food and tourist experiences}

Eating is considered a necessity and incorporating food within the tourist experience is beneficial for both the tourist and the provider. The shift in focus of the economy from service to experiences, as highlighted by Pine and Gilmore (1999), makes leveraging experiences valuable for both parties - tourists are willing to pay a premium for memorable experiences. To enhance experiences and making them memorable, there needs to be an emotional connection within which a person's senses are involved (Boswijk et al., 2006). This aspect can be intrinsically linked to tourists and unique gastronomic experiences. Food and drink can be both a primary or a secondary (peak and supporting) tourist experience (Quan \& Wang, 2004), However, 


\section{Copyright 2022 Cognizant Communication Corporation}

memorability of food experiences depends on various aspects, such as novelty (Quan \& Wang, 2004; Ritchie \& Crouch, 2003), opportunity to experience local cultures (Kim, 2014; Lin \& Mao, 2015), divergent from everyday life (Kivela \& Crotts, 2009), and amplified concentration by involving the senses (Kivela \& Crotts, 2006; Sutton, 2001). The diversity of studies connecting food and tourism illustrates the depth of research highlighting this key link. However, studies enabling tourists to sample and taste cuisine preceding immediate interviews are missing.

Many food studies, like broader tourist experience studies, follow a cognitive approach, with an emphasis on experiences formed within the mind (Goolaup et al., 2018; Larsen, 2007). They often involve an overview within which the food experience is seen through a holistic understanding of the different phases of the tourist trip - the pre-trip motivation phase (Kim, et al, 2009), during trip food experience phase (Cohen \& Avieli, 2004), and post-trip evaluation phase (Alderighi et al., 2016). However, these and other tourist food experience studies are mostly positivist enquiries whereby the experiences are conceptualised within an objective reality (Goolaup et al., 2018). Most studies concerning this topic are of a positivist quantitative nature (e.g., Getz \& Robinson, 2014; Mekoth \& Thomson, 2018; Rahman et al., 2018), which do not allow for participants to taste the food, and therefore that sense not being triggered. There has been limited qualitative interpretivist research on in situ food experiences of tourists, and the methods used in this study contributes to addressing this gap.

Tourist food experiences are also often observed through a sociological perspective. This stems from the studies of early tourism researchers' perceptions of tourists seeking experiences outside the norm (e.g., Cohen, 1979; MacCannell,1999; Smith, 1979), supported by similar aspects that arose from more recent studies (e.g., Uriely, 2005; Volo, 2009), which accept the importance of novelty within the tourist experience. While peak tourist experiences are usually associated with exploring attractions and visual gratification, and are often associated with the search for the unfamiliar (Quan \& Wang, 2004; Urry, 2002), food experiences within tourism are habitually inferred to be part of the everyday experience which satisfy basic needs (Björk \& Kauppinen-Räisänen, 2016; Quan \& Wang, 2004; Sánchez-Cañizares \& López-Guzmán, 2012), alongside sleeping and transportation, and therefore have received less attention in the tourism literature. However, post-modern interpretations blur the distinction between ordinary and novel (Uriely, 2005). This is emphasised in tourist food experience studies which highlight the important connection between the non-ordinary environment and food (Goolaup \& Mossberg, 2016; Quan \& Wang, 2004) leading to the embracing of the subjective view of food experiences. Food preferences and experiences are influenced by social contexts and individual sensory impressions (Chang et al., 2010; Mak et al., 2013; Quan \& Wang, 2004; Sthapit, 2017). The tasting buffet method utilised in this study assists in exploring these more subjective views of tourist food experiences.

\section{Literature review}

\section{Food tastings, the senses, and memory in tourism research}

Food is one of the few tourist activities that fulfil all the senses, enabling a sensual experience due to multidimensional feelings of each sense being affected (Neill et al., 2016). This study, however, mainly focusses on the sense of taste as that is the main sense when it comes to consuming food. Through an evolutionary process humans and other animals have conditioned themselves over generations to recognise and make decisions on what food will harm them and what food benefits them (Chambers, 2018), which highlights the durable and significant connection between food and memory. The sensory elements of eating create mnemonic 


\section{Copyright 2022 Cognizant Communication Corporation}

mechanisms through which food experiences are embodied as memory (Abarca \& Colby, 2016). Food provides a gateway to reminiscence of childhood experiences, nostalgia, self-identity, and cultural understandings (Choo, 2007; Lupton, 1994; Sutton, 2001). There have been several studies that explore the strong connections between specific senses and tourist experiences (e.g., Dann \& Jacobsen, 2003; Hjalager \& Richards, 2002), or focus on holistic, multisensual tourist experiences (e.g., Pan \& Ryan, 2009; Richards et al., 2010; Son \& Pearce, 2005). Other studies look at how different tastes elicit subjective descriptions, enhancing temporality of taste memory (Obrist et al., 2014). These studies provide valuable insights towards senses, specifically taste, and the memorability of tourist food experiences. This study aims to explore these connections between memories and taste, helping to elicit memorable recollections from participants, regarding their previous food travel, by tapping into food memories through actural taste sensations, experienced via the tasting buffet.

Food study participants within tourism studies, taking part in the act of eating and drinking, are rare. There are several studies which employ wine tastings to acquire various research insights (e.g., Bruwer et al., 2013; Charters \& Pettigrew, 2005) but few relate to the tourist experience (Viljoen et al., 2018). Other academic studies which utilise tastings focus on insect-based food research (e.g., Caparros Megido et al., 2016; Hartmann \& Siegrist, 2016; Menozzi et al., 2017) unrelated to tourism. Conducting food tastings as part of food tourism studies is missing from academic research. This study aims to contribute towards addressing this gap by introducing a method by which participants can taste the food before partaking in in-depth discussions of their food and travel experiences.

A study by Sthapit (2017) involved interviewing tourists who had visited Finland and had eaten local dishes. That study aimed to explore narratives of positive emotions and memorable experiences gained from savouring an unfamiliar local cuisine. Despite some similarities in the methods used by Sthapit's (2017) study and this study, there are notable differences. In terms of the sampling criteria for Sthapit's research, participants had to have visited Rovaniemi, Finland, within the last two years and eaten local food while at the destination. Various studies within different fields have highlighted the credibility of immediacy, compared to delayed interviews which could lead to an increase in imprecisions (e.g., Hagsand et al., 2017; Izotovas et al., 2020; Tuckey \& Brewer, 2001), therefore compromising trustworthiness and dependability.

This study of Maldivian guesthouse tourists is part of a larger study, requiring tourists to taste various local dishes and immediately participate in interviews discussing the sampled cuisine. The trustworthiness of the data collected is enhanced by the short time frame between the food tasting and the interviews (Guba \& Lincoln, 1991). The dependability of the immediacy aspect, however, is only related to the participants' perceptions of the local food that they have just consumed. The taste sensations experienced, leading to memorable evocations, do offer opportunities for participants to reminisce about previous experiences, which are explored in the broader study. The sensory aspects of consuming food prompts participants to recall strong memorable embodiments of previous food experiences, and to nostalgically reminisce towards aspects of self-identity and cultural understandings (Abarca \& Colby, 2016; Lupton, 1994; Sutton, 2001). This study then offers a method to explore how unfamiliar local cuisine experiences connect to the holistic experiences of tourists that may sample it, addressing the lack of tourism studies that have granted tourists the opportunity to sample local cuisine, prior to in-depth interviews recounting their unique food experiences and food memories. 


\section{Copyright 2022 Cognizant Communication Corporation}

\section{Guesthouse tourism and Maldivian cuisine}

This paper stems from a broader study conducted to investigate international tourist experiences of the burgeoning "guesthouse" (local island) tourism industry in the Maldives. The study involved discussions with international tourists visiting the Maldives, specifically staying at "guesthouses" on local islands, rather than tourists visiting the more established luxury resorts. The rapid growth of the guesthouse tourism industry from its modest beginnings a decade ago, and currently making up around a quarter of tourist beds available in the country (Ministry of Tourism, 2019), has led to more opportunities for tourists to sample the rarely documented local Maldivian cuisine.

As a tropical island nation with poor quality alkaline soil (Techera \& Cannell-Lunn, 2019; Stojanov, 2016), and the minor role of agriculture (1.1\% of GDP in 2019) (National Bureau of Statistics, 2020), it is not surprising that Maldives' cuisine is largely based on the natural products available, and to the limited produce that is grown locally. The 14th Century Moroccan explorer, Ibn Battuta, who documented his travels throughout the island nation, wrote of locals smoking and drying fish in palm baskets, and the importance of the coconut palm in providing milk, oil, and "honey" (coconut toddy (or rukuraa in Dhivehi)) for the local diet. This is the earliest known documentation of Maldivian food practices and few other historical records of traditional Maldivian cuisine, preceding the influence of imports and foreign cooking methods, exist.

As opposed to the unfertile soil, the marine environment - the tropical coral reef and the deeper oceans surrounding the islands, provide the foundation of Maldivian cuisine. Before imports of modern foreign influences, Maldivians lived a Spartan lifestyle of eating freshly caught fish, usually tuna, made into a broth and served with rice, onion, fresh chilli, and lime. This basic meal (garudhiya) is still served almost daily in many households throughout the country. A traditional breakfast item that is regularly served to tourists visiting guesthouses in the Maldives is mas huni. This is a mixture of tuna (these days usually a mixture of tinned tuna and finely chopped smoked, dried tuna), grated fresh coconut, chilli, and lime juice. This dish is eaten with roshi, a flatbread similar to the Indian roti, which is eaten with a variety of dishes at most mealtimes. Other meals and snacks typically combine fish, coconut, chilli, lime, and (imported) rice and flour products, and is cooked in a variety of ways (Ellis, 2008; Hussain et al., 2012; Romero-Frias, 1999, 2017; Shakeela, 2002). Most dishes and items are based around available local produce such as fish (especially tuna) and coconut, and there is a strong influence from the Asian sub-continent (roshi (roti), mugu riha (dhal curry), spices - cumin, coriander, turmeric).

Many of the flavours and dishes in the country have been influenced by the neighbouring countries of India and Sri Lanka, religion (Islam), and some of the cuisine and cooking methods can be traced back to the Portuguese, who invaded and ruled in the 16th century (Amin, 1993; Hogendorn \& Johnson, 1986; Hussain et al., 2012). However, the link between tourism and local cuisine in the Maldives is not a strong one. Instead of using local produce to make local dishes, most resorts in the Maldives usually serve up a version of "Westernised" international food with a lack of attention towards local cuisine (Fathimath \& Milne, 2011). This is often the case in developing tourism regions, and visitors that are in search of a more authentic experience related to local cuisine, are often left lamenting the lack of true local food prepared using authentic local cooking methods (Berno et al., 2016; Mangi \& Urassa, 2017). This study allowed tourists to sample the largely unfamiliar cuisine eaten by local Maldivians at a tasting buffet and reflect on their subjective food experiences. 


\section{Study Design \\ Paradigm}

Utilising an interpretivist paradigm, to gain a deeper understanding of tourists' guesthouse experiences, including their local and unfamiliar cuisine experiences, 41 participants took part in the tasting buffet of local food. Through the interpretivist paradigm, smaller samples can be used to generate theories from the results, with both the researcher and the participants involved within the study (Carson, 2001). Epistemologically, this study was conducted through a constructivist frame where the individual seeks to construct their meanings through experiences of interactions with others and society (Creswell, 2013; Neuman, 2014).

The subjective experiences of the researcher played a role in the research process. The researcher has in-depth knowledge and experience of local cuisine and is also a trained chef. Ontologically, the interpretivist paradigm is relevant because the study aims to understand the perceptions of the participating guesthouse visitors, with their multiple subjective realities and interpretations leading to knowledge creation. A relativist ontological báse was adopted to seek multiple realities, participants' distinct perspectives of food and holiday experiences, rather than a generalised understanding of the queries (Guba, 1990; Raskin, 2008). The subjective experiences and knowledge of the researcher enabled them to use their understanding to aid in the generation and construction of knowledge with the participants.

\section{Methods}

A total of 41 international guesthouse visitors, in three local islands in the Maldives, were recruited to participate in a food tasting of local cuisine, before being invited to participate in interviews. To recruit participants, international guesthouse tourists were approached. The aim was to recruit 20-25 participants total from the three islands for interviews. Qualitative research does not usually involve large samples (Mason, 2010), and little new information is attained from more than fifteen interviews (Green \& Thorogood, 2018).

The buffet was used partly as a recruitment tool for the interviews, and participation in the buffet did not mean they had to participate in the interviews. It was decided to aim to recruit 15 participants for the buffet, from each island (total of maximum 45 participants from the three islands). Convenience sampling was used to recruit participants. Convenience or nonrandom sampling targets participants based on practicality criteria such as accessibility (e.g., English speakers), geographical proximity, and willingness to participate (Saumure \& Given, 2008; Etikan et al., 2016). Participation in this research was voluntary with confidentiality offered to all respondents.

Tourists were approached at various guesthouses (with permission from operators) on the islands, and at recreational areas such as beaches and other public areas. Those showing interest were given detailed information about the research study and then they were invited to a free tasting buffet of local cuisine. The tourists were also notified that they would be invited to participate in interviews about their guesthouse and cuisine experiences. For the tasting, out of the 45 that had agreed to participate from the three islands, a total of 41 showed up at the venue - 14 participants from Dhiffushi, 13 from Thulusdhoo, and 14 from Maafushi. Permission to carry out the research was sought and approved by the university ethics committee. All participants also signed a consent form stating that the participants had no underlying food allergies. 


\section{Copyright 2022 Cognizant Communication Corporation}

On the buffet tables, all items were labelled, with the brief explanation of local dishes. The tasting buffet was laid out in a way that allowed for comparison between unfamiliar (to the tourists) local foods and well-known international dishes (see Figure 1). For example, a local breakfast item (rihaakuru - a salty fish paste, eaten with roshi) was placed next to a familiar international breakfast item (scrambled eggs), a main lunch time dish (tuna fish curry) was placed next to a familiar international dish (pasta), and so on. The participants were permitted to choose what they liked to eat. Table 1 lists the dishes that were offered to the study participants. The way the dishes were arranged with a choice of familiar international dishes, and unfamiliar local dishes, allowed for observations of the participants reactions to the food choice. This would lead to further questioning of why they had made those choices, during the interview process, and regarding previous unfamiliar and familiar cuisine holiday experiences.

Figure 1: Sample of the layout of the buffet-international dish (pasta) next to a local dish (mas riha)

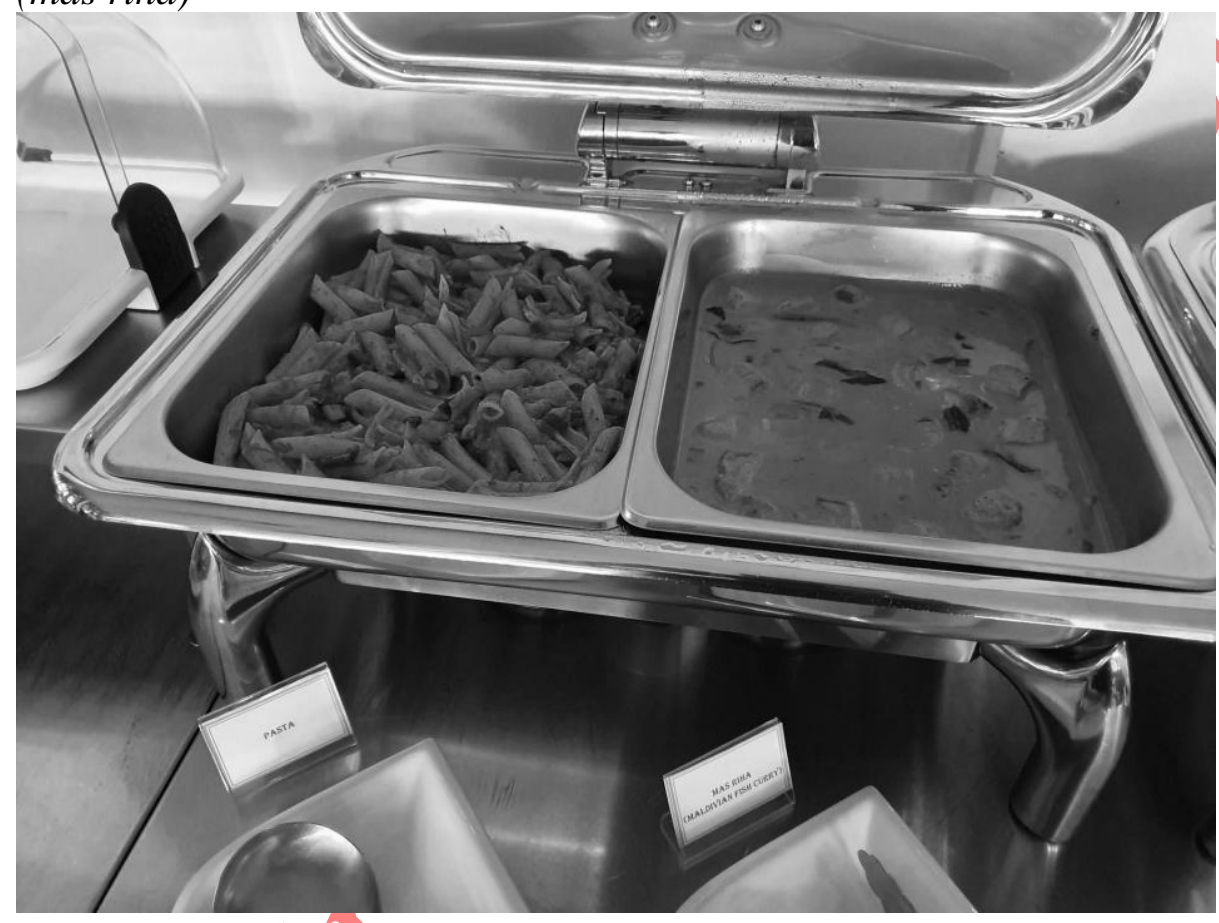

The tasting buffet table was photographed before and after the participants took their food and the food choices of the participants were noted. This aided with observing and recording what items they chose and led to contributions during the interview process where the participant was questioned on their choices and the reasons why they made those choices, adding a further dimension to the explorations. Observation is often used in qualitative research to collect data, to record activities and interactions (Angrosino, 2007). However, as observation is usually momentary, photography was used to overcome this briefness and provide an accurate reminder of the situational context (Prince \& Basil, 2011). Photographs allows the researcher time to reflect and can provide rich and descriptive data during qualitative analysis (Deshpande, 1983). The photographs of the buffet were used during the interview process to prompt the participants to remember their choices of food. 
Table 1: Food tasting dishes

\begin{tabular}{|c|l|l|}
\hline MEAL & \multicolumn{1}{|c|}{$\begin{array}{c}\text { LOCAL (MALDIVIAN) } \\
\text { DISH }\end{array}$} & $\begin{array}{c}\text { TYPICAL } \\
\text { GUESTHOUSE } \\
\text { DISH (INTERNA- } \\
\text { TIONAL) }\end{array}$ \\
\hline BREAKFAST & $\begin{array}{l}\text { Mas } \text { huni } \text { - Tuna, coconut \& } \\
\text { lime, served with roti } \\
\text { Rihaakuru } \text { - Salty fish paste, } \\
\text { served with roti }\end{array}$ & $\begin{array}{l}\text { Scrambled Eggs \& } \\
\text { Toast }\end{array}$ \\
\hline LUNCH & $\begin{array}{l}\text { Garudhiya } \text { - Clear tuna fish } \\
\text { broth served with rice }\end{array}$ & $\begin{array}{l}\text { South-east Asian Fried } \\
\text { Rice }\end{array}$ \\
\hline AFTERNOON TEA & $\begin{array}{l}\text { Hedhikaa } \text { - snacks, fried tuna } \\
\text { fish balls, tuna samosas }\end{array}$ & Club Sandwich \\
\hline DINNER & $\begin{array}{l}\text { Mas riha } \text { - Spicy tuna fish curry } \\
\text { with coconut, served with rice }\end{array}$ & Pasta \\
\hline DESSERT & Foni boakibaa - Coconut Cake & Chocolate Mousse \\
\hline
\end{tabular}

Although the increase in credibility due to immediacy has been highlighted, some studies on consumer decision making behaviours reveal that often, participants may not accurately recount their behaviours when self-reporting during surveys or interviews due to lack of willingness or awareness (e.g., Gram, 2010, Tinson et al., 2008; Wang et al., 2007). Therefore, observation would offer a more accurate method of collecting data and offered a route for the researcher to remind the participant of their choices, as was done during the interview process (Gram, 2010). In this instance, the researcher was a complete participant, interacting with and engaging with the participant to establish rapport (Angrosino, 2007; Creswell, 2013). Additionally, each participant was given a brief questionnaire to fill in during the tasting, to determine their enjoyment of the dishes. This aided the researcher during the interview process to determine the participants' taste preferences concerning the local food and acted as a prompt for the participants when recalling the tasting, which led to further discussions of their previous holiday food memories.

As they were eating, participants were asked whether they would be willing to participate in interviews. Twenty-eight of the buffet participants agreed to participate in in-depth, face-toface semi-structured interviews. This exceeded the goal of recruiting 20-25 participant for the interviews. These types of interviews encourage participants to express rich, descriptive, narratives of the enquiries of the study (Jordan \& Gibson, 2004; Yin, 2014). The semi-structured interview process has a degree of predetermined questions which acted as a guide to cover the issues at hand. They aim to establish a rapport with participants, offering them the opportunity to provide subjective, multiple realities to the enquires. The open-ended questions point the interviewee in the appropriate direction, with clarifying queries and follow-up questions providing deeper understanding of the queries (Collis \& Hussey, 2003; Jordan \& Gibson, 2004). The interviews thus explored the participants' holiday food preferences and memories, and their experiences with local cuisine by tapping into their sensory experiences. 


\section{Copyright 2022 Cognizant Communication Corporation}

\section{Data Analysis}

Gathered data was first transcribed and to enhance rigour and reliability of the findings, detailed thematic analysis was conducted. This involved familiarisation with the data, and coding, identification, organisation, and development of themes from the data. Table 2 provides a simplified example of the themes that arose and how they developed from the analysis.

Table 2: Major themes and interview themes below that arose from the analysis (participant interview number in brackets - see Table 3)

\begin{tabular}{|c|c|c|c|}
\hline $\begin{array}{c}\text { Neophilia \& neo- } \\
\text { phobia }\end{array}$ & $\begin{array}{l}\text { Experiencing lo- } \\
\text { cal culture }\end{array}$ & $\begin{array}{l}\text { Sensory recall - } \\
\text { food memories }\end{array}$ & $\begin{array}{c}\text { No interest in } \\
\text { food }\end{array}$ \\
\hline $\begin{array}{l}\text { Wants to try everything } \\
(5 \& 6)\end{array}$ & $\begin{array}{l}\text { Food a cultural experi- } \\
\text { ence }(1 \& 2)\end{array}$ & $\begin{array}{l}\text { Vivid recollections of } \\
\text { trying food while trav- } \\
\text { elling - unfamiliar } \\
\text { food, learning about } \\
\text { food habits of locals } \\
(9 \& 10)\end{array}$ & $\begin{array}{l}\text { Food as fuel for activi- } \\
\text { ties (13) }\end{array}$ \\
\hline $\begin{array}{l}\text { Stick to western food } \\
\text { when travelling (11) }\end{array}$ & $\begin{array}{l}\text { Trying all food is part } \\
\text { of the local experience } \\
(5 \& 6)\end{array}$ & $\begin{array}{l}\text { Positive memories of } \\
\text { eating local food on a } \\
\text { previous trip (15) }\end{array}$ & \\
\hline $\begin{array}{l}\text { Wants more local food } \\
\text { - not available, not } \\
\text { healthy (15) }\end{array}$ & $\begin{array}{l}\text { Went searching for lo- } \\
\text { cal food on the island } \\
\text { - local restaurant (14) }\end{array}$ & $\begin{array}{l}\text { Memories of trying } \\
\text { food in China, Kenya, } \\
\text { Egypt (26) }\end{array}$ & \\
\hline $\begin{array}{l}\text { Not a foodie, stick to } \\
\text { familiar foods (16) }\end{array}$ & $\begin{array}{l}\text { Got cooking lessons of } \\
\text { local food (17) }\end{array}$ & $\begin{array}{l}\text { Food enhances the } \\
\text { senses (24) }\end{array}$ & \\
\hline $\begin{array}{l}\text { Like to sample local } \\
\text { dishes but likes the fact } \\
\text { there is western food } \\
\text { available (18) }\end{array}$ & $\begin{array}{l}\text { Always try the local } \\
\text { food first few days } \\
\text { when travelling (19) }\end{array}$ & 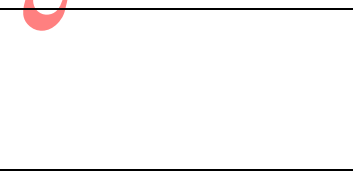 & \\
\hline \multirow[t]{2}{*}{$\begin{array}{l}\text { Wants to try everything } \\
\text { (26) }\end{array}$} & $\begin{array}{l}\text { Food is a major part of } \\
\text { the culture, experi- } \\
\text { ence, (24) }\end{array}$ & & \\
\hline & $\begin{array}{l}\text { Eating local food is } \\
\text { part of the cultural ex- } \\
\text { perience }(20 \& 21)\end{array}$ & & \\
\hline
\end{tabular}

\section{Findings}

\section{Overall profile of the participants}

A total of 28 buffet participants agreed to participate in in-depth interviews. As shown in Table 3, there were 15 female and 13 male participants interviewed on three islands, with pseudonyms used for their names. Their ages ranged from 19 to 48 and their country of origin was highly diverse, representing twelve countries from Europe, USA, India, United Arab Emirates (UAE), and Israel. Their overall length of stay was also varied, from four days to 21 days. 
Table 3: Profile of participants

\begin{tabular}{|c|c|c|c|c|c|c|}
\hline Participant & $\begin{array}{c}\text { Country of } \\
\text { origin }\end{array}$ & Sex & Age & Island & Guesthouse & $\begin{array}{c}\text { Length } \\
\text { of stay (Length } \\
\text { of total stay in } \\
\text { the Maldives) }\end{array}$ \\
\hline 1. Lina & Russia & $\mathrm{F}$ & 27 & Dhiffushi & Ameera & 10 \\
\hline 2. Iya & Russia & M & 27 & Dhiffushi & Ameera & 10 \\
\hline 3. Rico & Spain & $M$ & 39 & Dhiffushi & Bibee & $4(12)$ \\
\hline 4. Lia & Spain & $\mathrm{F}$ & 48 & Dhiffushi & Bibee & $4(12)$ \\
\hline 5. Lila & Spain & $\mathrm{F}$ & 19 & Dhiffushi & Portia & $3(10)$ \\
\hline 6. Emi & Spain & $\mathrm{F}$ & 40 & Dhiffushi & Portia & \\
\hline 7. Julia & Romania & $\mathrm{F}$ & 25 & Dhiffushi & Ameera & \\
\hline 8. Nico & Romania & $\mathrm{M}$ & 27 & Dhiffushi & Ameera & 9 \\
\hline 9. Jasmine & France & $\mathrm{F}$ & 28 & Dhiffushi & Araamu & $10 y$ \\
\hline 10. Laura & Germany & $F$ & 28 & Dhiffushi & Araamu & 10 \\
\hline 11. Greg & Romania & $\mathrm{M}$ & 20 & Thulusdhoo & ReefEdge & 4 \\
\hline 12. Omal & Israel & M & 24 & Thulusdhoo & Surf Deck & $10(11)$ \\
\hline 13. Nur & Israel & $\mathrm{M}$ & 21 & Thulusdhoo & Surf Deck & 21 \\
\hline 14. Joseph & Israel & M & 47 & Thulusdhoo & Surf Deck & 8 \\
\hline 15. Iyona & Russia & $\mathrm{F}$ & 31 & Thulusdhoo & Isóla & 16 \\
\hline 16. Cody & Israel & $\mathrm{M}$ & 47 & Thulusdhoo & Reef Edge & 11 \\
\hline 17. Audrey & USA & $\mathrm{F}$ & 29 & Maafushi & Sting Ray & $2(10)$ \\
\hline 18. Kristel & Germany & $\mathrm{F}$ & 25 & Maafushi & Liyela & 21 \\
\hline 19. Melinda & Denmark & $\mathrm{F}$ & 23 & Maafushi & Arena & 14 \\
\hline 20. Mandi & India & $\mathrm{F}$ & 35 & Maafushi & Arena & $8(9)$ \\
\hline 21. Sanchi & India & $\mathrm{F}$ & 35 & Maafushi & Arena & $8(9)$ \\
\hline 22. Betty & Italy & $\mathrm{F}$ & 28 & Maafushi & Arena & 10 \\
\hline 23. Victor & Italy & $\mathrm{M}$ & 21 & Maafushi & Arena & 10 \\
\hline 24. Carl & UAE & $\mathrm{M}$ & 35 & Maafushi & Arena & 8 \\
\hline 25. Edward & UAE & M & 43 & Maafushi & Kaani Grande & 8 \\
\hline 26. Colin & UAE & M & 38 & Maafushi & Arena & 8 \\
\hline 27. Tommy & Netherlands & M & 31 & Maafushi & Arena & 4 \\
\hline 28. Ela & Netherlands & $\mathrm{F}$ & 29 & Maafushi & Arena & 4 \\
\hline
\end{tabular}

The methods used for this study proved to be an excellent and efficient way to recruit and interview participants. The majority of those approached to take part in the buffet tasting were keen to participate. An audit of guesthouse restaurant menus preceding the research had discovered that only $2 \%$ of dishes on the menus were traditional Maldivian dishes, and so there was a positive reaction by the participants towards being able to taste local dishes. The 41 buffet participants all completed a scaled survey to determine the participants' taste preferences concerning the local food which acted as a prompt for interview participants when recalling the tasting. As can be observed in Table 4, most dishes received generally favourable responses ("Would definitely choose" and "Might choose"). 


\section{Copyright 2022 Cognizant Communication Corporation}

Table 4: Tasting buffest survey results

\section{HOW LIKELY ARE YOU TO CHOOSE THIS DISH IF IT WAS ON A GH MENU?}

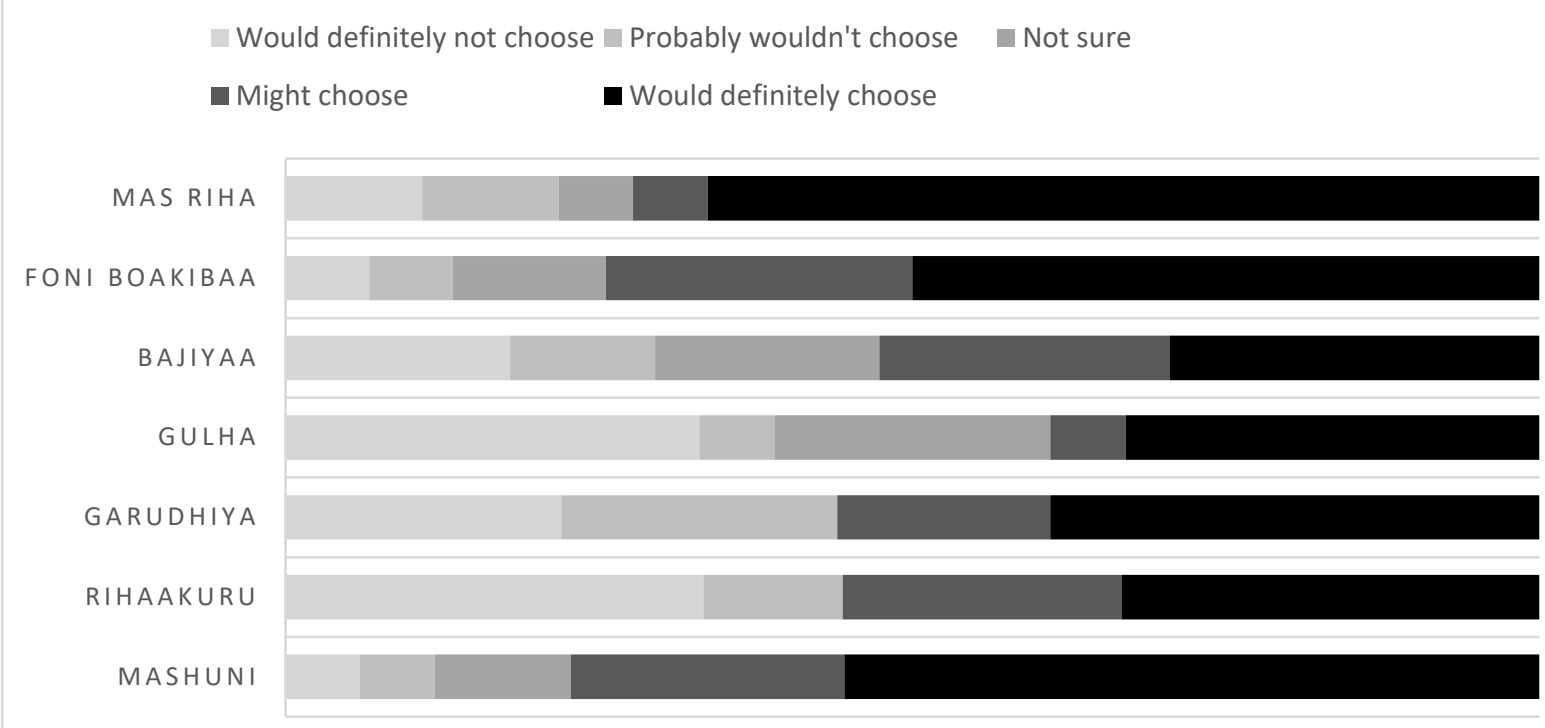

Several themes arose from analysing the responses of the participants, which are highlighted in the discussion of the findings below.

\section{Neophilia and neophobia}

During the tasting process, the participants were curious about what local dishes contained and several asked questions to clarify the unfamiliar food items. As stated, the local dishes were placed alongside typical guesthouse dishes, to allow for comparison and participants could choose any of the dishes they wished to. Some participants did gravitate towards the familiar dishes, such as pasta, but most were keen to try the unfamiliar local dishes. Some participants highlighted an aversion to sampling unfamiliar cuisine. When questioned about this during the interview, the participants who mainly chose familiar dishes outlined the reasons why, stating that they were not very adventurous when it came to sampling unfamiliar food. Nur (13), a 21-year-old surfer from Israel stated:

I don't like to try new stuff. I don't really like new food. I eat something I like, and I stick to it.

Cody (16), a 47-year-old from Israel stated:

I'm not... I wouldn't consider myself a "foodie”. I stay safe, familiar.

Only five of the participants exhibited strong neophobic tendencies, instead most participants demonstrated neophilia. 


\section{Copyright 2022 Cognizant Communication Corporation}

Others stated that they simply did not like fish. Greg (12) a 20-year-old Romanian travelling by himself was asked why he displayed low preference for some of the dishes on the survey:

Well, it's a lot of fish and I don't actually eat that much fish... The tuna soup yea it was really fishy for me, I didn't like that.

Some participants were deterred by the spice level. Edward (25), a Brazilian living in South Africa, was put off by the chilis:

It's chilis and hot and spicy, and you don't eat it, what can you do?

All the savoury dishes contained the staple local protein, tuna, in some form and all contained chilli.

This layout of dishes, with an unfamiliar local dish placed next to a corresponding more familiar dish, and the choice presented to participants offered opportunities for the researcher to observe their decision-making process. This led to contributions during the interview process where the participant was questioned on their choices and the reasons why the made those choices, adding a further dimension to the explorations.

From observation, it was insightful to see how the participants reacted towards some of the dishes, illustrating their neophiliac and neophobic tendencies. One of the dishes "garudhiya" is a clear tuna broth made with tuna, including the fish head (see Figure 3). Some participants opened the serving dish, and on observing the fish head, promptly closed it.

Figure 3: "Garudhiya" - Tuna Fish broth încluding fish head

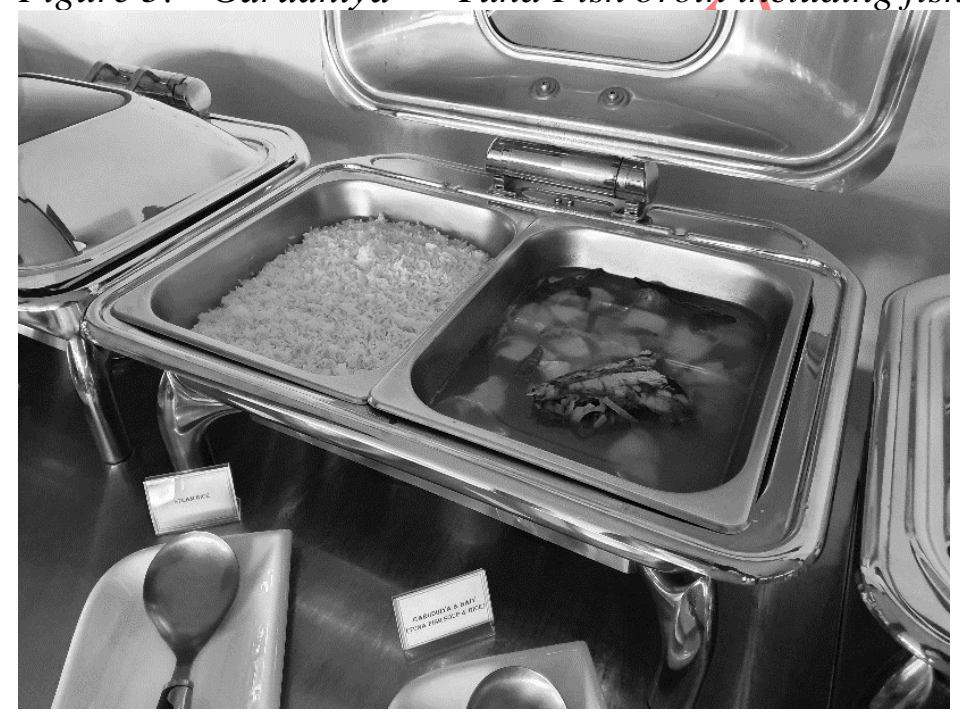

When questioned about this during the interviews, Julia (7) 27 , seemingly repelled by the fish head stated:

We didn't try the fish soup because it's not something we're used to and we don't like how it looks, the head. 


\section{Copyright 2022 Cognizant Communication Corporation}

Other participants reacted differently to the fish head. When Victor (23), a 21-year-old from Italy, was told that he had been observed showing interest, he demonstrated his neophiliac tendencies:

The fish head? That's not too extreme. I like trying different stuff.

Other participants Emi (6), 40-years-old, and her niece Lila (5), 19-years-old, from Spain, also demonstrated neophilia by highlighting the pre-trip research that they conducted, in search of local cuisine:

We know restaurants, we have been looking for reviews. For reviews from different restaurants. We want to taste everything.

Colin (26), a Brazilian living in Dubai was boastful about the food he had eaten while travelling:

I tried all the street food you could possibly have imagined.

Colin's travelling companion Carl (25), was keen on trying unfamiliar dishes when travelling but his cautiousness held him back from fully experimenting:

I would like to choose cuisine from different cultures, but I'm very picky when it comes to, I'm like, I want that but, "Is that raw? Or is that organ based or not". I would first want some information before I would trial it.

Overall, most participants, despite caution for some, demonstrated neophiliac tendencies, wanting to sample unfamiliar dishes even if in the end they did not like it. They felt this was part of traveling and experiencing different cultures, which is another theme that arose from the interviews.

\section{Experiencing local culture}

One of the major themes that emerged from the interviews was the participants' desire to experience the local culture via eating the local cuisine. Rico (3) and his partner Lia (4) emphasised this when questioned:

We always try to taste the local food. I would say it's a highlight.

Jasmine (9) from France, and her friend Laura (10) living in Germany, agreed:

Ithink it's part of the whole travelling thing... it's part of the cultural experience.

Carl (25) spoke passionately when he described his thoughts of eating local food when travelling:

Food is a common ground across any culture... why would you travel to a country, and you just eat pizza? It's part of the experience, seeing the world, tasting the world, part of the senses, isn't it? 


\section{Copyright 2022 Cognizant Communication Corporation}

Many participants hoped that staying at a local island guesthouse would offer them the opportunity to experience local cuisine. When this was not available at their destination, they went in search for it. Rico (3) mentioned:

In Thulusdhoo, we found a small local restaurant. It had local food and some international food, but we tried to taste local food. We love it. All the days, lunch and dinner there.

Joseph (14) from Israel had a similar experience:

I go with my friend around the island, and he told me I want to eat local food, so we asked someone "where is the local restaurant?" and he told us about it, and we eat there. Very nice. We eat some fish soup. They don't have a lot of local food here. Usually, we try the local places when travelling, not just the tourist places. It's the culture.

Audrey (17), a 29-year-old solo female traveller from America experienced some local food culture:

They gave me some cooking lessons, taught me how to make mashuni. I asked.

Iya, from Russia on his honeymoon, emphasised what he searched for when travelling:

We're looking for different experience, and the food experience is the second one after the classical cultural experience.

The search for authenticity and "real" tourism experiences is a strong motivator for tourists (Richards, 2002; Sharpley \& Sundaram, 2005), as well as being a significant way to promote a destination (Horng \& Tsai, 2012). Participants of this study related their experiences of eating unfamiliar cuisine by recalling previous memorable experiences.

\section{Food memories and sensory recall}

Allowing participants to sample local, usually unfamiliar cuisine preceding immediate interviews, led to several of them discussing vivid food memories from previous travel experiences, often unprompted. The discussions led to recall of incidents of travel food consumption and food culture practices from previous holidays experiences.

Audrey, an experienced traveller who had visited thirty-two countries, spoke of her travels in South America:

If you go to Peru... you can eat like a guinea pig. I tried that.

Audrey was prompted to discuss her unfamiliar food experiences, and despite being extremely well travelled, she only mentioned this incident, a somewhat stereotypical experience for foreign travellers to Peru. Her lack of other examples perhaps highlighted that she was not as adventurous with unfamiliar cuisine as she claimed to be.

Omal also discussed his visit to the Americas. At this point, he had not been prompted to discuss other travel cuisine experiences. As a liberal vegan, he was discussing his experience with the tasting buffet where he was not keen to try much of the food: 


\section{Copyright 2022 Cognizant Communication Corporation}

In Central America, in their culture they have a lot of vegan food... there is a lot of restaurants that do care about it like they know that there's a lot of vegans and they're all around the world and they're travellers.

The lack of non-vegan food at the buffet and at his accommodation, led him to recall previous travel experiences where his diet was catered for more adequately.

Other participants discussed travel food experiences and related them to cuisine from home. Greg talked about his experience of eating food in China:

It was horrible. So, what you eat in Europe, the Chinese food is nothing like. The Chinese food is super good in Europe I love it but in China it is horrible. Well, it's odd, for a European it's odd.

Iyona, a Russian who grew up in Israel, and had travelled extensively, bemoaned the lack of variety in the cuisine available in the Maldives:

Like from the place I came a lot of different kinds of food Middle East, you know, Middle East various kinds of food.... I travelled in Mexico. Every corner someone selling stuff.

Colin described in vivid detail about his experience while travelling in Kenya, and other experiences:

We were in a restaurant, the floor was like this (pointing to the sand), there was no fridge, but they had the best chicken stew that I ever ate in my life. We eat with our hands. When I asked for a fork, I realised people there run around to find me a fork, and I said "no, no, we eat'. So, we eat chicken stew with cassava ... you have no idea what I've tried, in China, everywhere.

Colin spoke passionately about his love of trying unfamiliar cuisine while travelling and used his Kenya experience and others, to highlight his strong feelings towards being adventurous with cuisine when traveling.

The most vivid descriptions of their experiences came from Laura, she animatedly discussed her experiences:

In Thailand it's very spicy. I was telling her this yesterday, I tried a papaya salad, and Ididn't know it was spicy and I couldn't eat during four days. It was crazy but I really liked what they did like Pad Thai for sure... There is something they did for dessert I think it's like crêpe. It looks like a French crêpe, but it was not. They cut it in small pieces it was very good. It was fried. It's like pancakes. In French we say crêpes. It was fried but it was very good.

It was interesting how Laura discussed her travel experiences, comparing them to familiar experiences from home. Her observation and mimicking locals' purchasing behaviours in supermarkets, during her travels, was for her, a cultural experience. Tourists, like Laura, who copy locals' habits, or try to live like the locals, are searching for the "authentic" local 


\section{Copyright 2022 Cognizant Communication Corporation}

experience and may aim to disassociate themselves with the stigma associated with being a mass-tourist who participates in over-simplified local culture (Chen, 2014; Urry, 2002).

The above examples of subjective descriptions of memories of food and food culture, provide insightful and sensory understandings of tourist experiences, relating to tourism gastronomy.

\section{Discussions}

Discussions following on from the tasting buffet led to participants highlighting, in most cases, their food neophiliac tendencies. A minority of participants also emphasised their aversion to tasting unfamiliar cuisine. Some tourism and food research suggest that tourists tend to be more conservative with food choices while travelling (Torres, 2002). This can be identified as food neophobia, which is defined as behaviour that rejects or avoids unfamiliar food or flavours (Dimitrovski, \& Crespi-Vallbona, 2017; Johns et al., 2011). This study also highlights the concept of embodiment within the tourism experience, which has been previously neglected (Palmer \& Andrews, 2019). Embodiment introduces senses such as smell and taste into tourism studies, as it does in this study with the tasting buffet. Sensual experiences with food, especially unfamiliar food, leads to reliving positive and negative holiday memories through sensory recall (Schänzel, \& Lynch, 2016), as highlighted in this study. There were some participants who had little interest in food, mainly surf tourists from Israel. Eating was a secondary focus for them. It was a way for them to refuel, before going out to sea again. This food indifference sits outside the neophobia/neophilia framework making a unique contribution.

Food neophilia is the opposite of food neophobia, where-by tourists have a positive attitude of sampling unfamiliar foods, gaining pleasure from, and being motivated to travel due to, the opportunity to eat unknown local dishes (Chang \& Yuan, 2011; Kim et al., 2010). Many participants of this study associated travelling with exploration and desire to experiment, even if in the end, they did not enjoy the food. The participants' desire to eat local unfamiliar food was often related to their wish to experience local culture.

All the participants were staying at local island accommodation, away from the typical luxury resorts that the Maldives is traditionally known for. One of the main motivations for choosing this type of accommodation (aside from the obvious affordability factor) was the desire to experience a local culture that most were unfamiliar with, including the local cuisine, as discussed in previous studies (e.g., Richards, 2002; Sharpley \& Sundaram, 2005). Various studies within tourism literature have highlighted the importance of exploring local culture as a strong motiyator for travel. Food as a cultural attraction for tourists (Hjalager \& Corigliano, 2000), and as a significant way to promote a destination has been addressed. Participation within local cultural experiences while travelling as highlighted above, such as eating the food locals consume, and eating in restaurants that the local eat in, allows the traveller to immerse themselves within the culture of the destination. This creates stronger bonds between the tourist, their experience, the destination, and its culture (Pine \& Gilmore, 1999), leading to significantly more memorable experiences (Kim, 2014; Morgan \& Xu, 2009). Reminiscence of previous food experiences and sensory recall was another major theme that arose from this study.

For many participants, tasting the unfamiliar local cuisine at the tasting buffet, and therefore experiencing the local culture, led to reminiscence of previous travel food experiences. This was the area that most animated discussions occurred. Several participants, especially those 


\section{Copyright 2022 Cognizant Communication Corporation}

that stated that they were adventurous with their food choices, described in vivid detail their past cuisine experiences. As highlighted previously, various studies have connected the sensory elements of consuming food with enhanced memories, leading to subjective reminiscence, nostalgia, and cultural understandings (e.g., Abarca \& Colby, 2016; Choo, 2007; Sutton, 2001). This study supports previous findings (see Björk \& Kauppinen-Räisänen, 2016; Quan \& Wang, 2004) that holiday food consumption leads to memorable tourist experiences. Despite the conformity with some previous findings, this study's approach of necessitating participants to sample unfamiliar cuisine before discussions is a novel method to elicit sensory rich results from participants' interviews. The significant contribution of this study is the valuable way that the tasting buffet contributed towards the evocation and embodiment of sensory food and travel memories from participants.

\section{Conclusions}

The intimate but inextricable link between tourism and food requires in-depth exploration. There has been a growing focus on this link in academia, through a diverse prism of topics, especially in recent times. However, studies of tourist food experiences have been neglected. The focus of tourist food experience research tends to not enable the tourist to participate in the act of tasting the food. By enabling tourists to sample local, unfamiliarcuisine, in a controlled setting as offered by this study, it closes this gap by enabling active participation, heightening the senses, and leading to expansive elicitation.

Several tourist and cuisine related themes arose from the analysed data from discussions with the participants. This included neophilia and neophobia, food indifference, local cuisine as local culture, and recall of memorable cuisine travel experiences. The tasting buffet as a method allowed to garner the information previously not utilised in tourism research, thus adding the importance of sensory food memories to the experiential aspects of travelling, which is linked to the eagerness of the tourist to participate in immersive and memorable experiences (Pine \& Gilmore, 1999).

This study was limited to three islands and three buffets, each with 11 items, due to research costs and timeframes. Further explorations could expand the study to more guesthouse islands, with more buffets, and a greater variety of food choices, perhaps eliciting richer results, from a larger sample, increasing generalisability. The local food items chosen were the most common local dishes and a few of the items were familiar to tourists. There are regional variations of food within the Maldives. Expansion of the study to further regions would have allowed participants to sample even fewer familiar dishes, perhaps leading to even more observations and results. The simplicity and flexibility of this research method offers the opportunity to expand to more research locations, within the Maldives and beyond. Most of the participants were Westerners. It would have been useful to have a wider-cross section of participants, from different regions as food perceptions and attitudes are influenced by and linked to cultural background.

Despite the connection between food and all the senses, this study focussed mainly on the sense of taste and perceptions stemming from that. Future studies could highlight other senses - by enhanced visual presentation of the dishes, and perhaps a live cooking demonstration prior to the buffet by chefs, to highlight smell, taste, audio, and visual senses. The sense of touch could also be explored by participants using their hands to eat, without cutlery, which is the common method of eating in the Maldives. The interview questioning could then highlight aspects of these senses and the perceptions stemming from the other senses being engaged. 
Results from using this method, such as the evocation of sensory memories (positive and negative) is a significant contribution of this study. The strong connection between food and memory has been highlighted in previous studies. This study supports this and offers a method by which these sensory connections can be explored and articulated, especially relating to previous food tourism experiences. It introduces embodiment of taste into tourism studies which arguably have been neglected to date (Schänzel \& Lynch, 2016) and highlights the repercussions of reliving positive and negative holiday memories and sensations. The responses from participants in this study are particularly resonant, stemming from the enhanced sensual experience from participating in tasting the cuisine, immediately before discussions. The methods of this study are flexible and adaptable. The imperative factor is the requirement for opportunities for participants to sample cuisine in a controlled setting, such as a tasting buffet, followed immediately by interviews. Future studies researching tourist food experiences would benefit from utilising similar methods.

By gaining an understanding of the food perceptions of tourist participants, this study could pave the way for further explorations of local cuisine experiences in the Maldives. This can help develop and leverage gastronomic tourism within the burgeoning guesthouse tourism industry leading to strengthening of linkages between tourism and local community development, including follow on benefits for the local agricultural industry. Similar benefits can apply for other developing destinations where local cuisine tourism experiences have been neglected (Berno et al., 2021). There could also be opportunities for non-tourism focussed studies to utilise the methods, to provoke recollections of memorable food experiences.

\section{References}

Abarca, M. E., \& Colby, J. R. (2016). Food memories seasoning the narratives of our lives. Food and Foodways, 24(1-2), 1-8. https://doi.org/10.1080/07409710.2016.1150101

Akyuz, B. G. (2019). Factors that influence local food consumption motivation and its effects on travel intentions. Anatolia, 30(3), 358-367. https://doi.org/10.1080/13032917.2019.1595072

Alderighi, M., Bianchi, C., \& Lorenzini, E. (2016). The impact of local food specialities on the decision to (re)visit a tourist destination: Market-expanding or business-stealing? Tourism Management, 57, 323-333. https://doi.org/10.1016/j.tourman.2016.06.016

Amin, M. (1993). Journey through Maldives. Hunter Pub Inc.

Angrosino, M. V. (2007). Doing ethnographic and observational research. SAGE.

Berno, T., Rajalingam, G., Miranda, A. I., \& Ximenes, J. (2021). Promoting sustainable tourism futures in Timor-Leste by creating synergies between food, place and people. Journal of Sustainable Tourism, 1-15. https://doi.org/10.1080/09669582.2021.1895819

Berno, T. Milne, S., Thorburn, E., Sun, M., Oksanan, N., Pladdet, A. (2016, February). Sun, sea, sand, and sustenance: Food and tourism in the Cook Islands. Paper presented at the 26th CAUTHE conference, Sydney, Australia.

Berno, T. (2011). Sustainability on a plate: Linking agriculture and food in the Fiji Islands tourism industry. In R. Torres and J. H. Momsen (Eds.), Tourism and agriculture, (pp. 87-103). Routledge.

Björk, P., \& Kauppinen-Räisänen, H. (2016). Local food: A source for destination attraction. International Journal of Contemporary Hospitality Management, 28(1), 177-194. https://doi.org/10.1108/IJCHM-05-2014-0214

Boswijk, A., Thijssen, T., \& Peelen, E. (2006). A new perspective on the experience economy. Meaningful experiences. Pearson Education. 


\section{Copyright 2022 Cognizant Communication Corporation}

Bruwer, J., Coode, M., Saliba, A., \& Herbst, F. (2013). Wine tourism experience effects of the tasting room on consumer brand loyalty. Tourism Analysis, 18(4), 399-414. https://doi.org/10.3727/108354213X13736372325957

Caparros Megido, R., Gierts, C., Blecker, C., Brostaux, Y., Haubruge, É., Alabi, T., \& Francis, F. (2016). Consumer acceptance of insect-based alternative meat products in Western countries. Food Quality and Preference, 52, 237-243. https://doi.org/10.1016/j.foodqual.2016.05.004

Carson, D. (2001). Qualitative marketing research. SAGE.

Chambers, K. C. (2018). Conditioned taste aversions. World Journal of Otorhinolaryngology - Head and Neck Surgery, 4(1), 92-100. https://doi.org/10.1016/j.wjorl.2018.02.003

Chang, R. C. Y., Kivela, J., \& Mak, A. H. N. (2010). Food preferences of Chinese tourists. Annals of Tourism Research, 37(4), 989-1011. https://doi.org/10.1016/j.annals.2010.03.007

Chang, W. C., \& Yuan, J. (. (2011). A taste of tourism: Visitors' motivations to attend a food festival. Event Management, 15(1), 13-23. https://doi:10.3727/152599511X12990855575024

Charters, S., \& Pettigrew, S. (2005). Is wine consumption an aesthetic experience? Journal of Wine Research, 16(2), 121-136. https://doi.org/10.1080/09571260500327663

Chen, D-J. (2014). Learning to perform the exotic: cosmopolitan imagination, participation and self-transformation among Taiwanese couchsurfers. In D. Picard and S.

Buchberger (Eds.), Couchsurfing Cosmopolitanisms, (pp. 107-122). Transcript Verlag.

Choo, S. (2004). Eating Satay Babi: Sensory perception of transnational movement. Journal of Intercultural Studies, 25(3), 203-213. https://doi.org/10.1080/0725686042000315722

Cohen, E., \& Avieli, N. (2004). Food in tourism-Attraction and impediment. Annals of Tourism Research, 31(4), 755-778. https://doi.org/10.1016/j.annals.2004.02.003

Cohen, E. (1979). A Phenomenology of Tourist Experiences. Sociology, 13(2), 179-201. https://doi.org/10.1177/003803857901300203

Collis, J., \& Hussey, R. (2014). Business research: A practical guide for undergraduate \& postgraduate students. Palgrave Macmillan.

Cornelis, M. C., Tordoff, M. G., El-Sohemy, A., \& van Dam, R. M. (2017). Recalled taste intensity, liking and habitual intake of commonly consumed foods. Appetite, 109, 182189. https://doi.org/10.1016/j.appet.2016.11.036

Creswell, J. W. (2013). Qualitative inquiry \& research design: Choosing among five approaches. SAGE.

Dann, G., \& Jacobsen, J. K. S. (2003). Tourism smellscapes. Tourism Geographies, 5(1), 325 https:/doi.org/10.1080/1461668032000034033

De Jøng, A., Palladino, M., Puig, R. G., Romeo, G., Fava, N., Cafiero, C., Skoglund, W., Varley, P., Marcianò, C., Laven, D., \& Sjölander-Lindqvist, A. (2018). Gastronomy tourism: An interdisciplinary literature review of research areas, disciplines, and dynamics. Journal of Gastronomy and Tourism, 3(2), 131-146. https://doi.org/10.3727/216929718X15281329212243

Deshpande, R. (1983). 'Paradigms lost': On theory and method in research in marketing. Journal of Marketing, 47(4), 101-110.

Dimitrovski, D., \& Crespi-Vallbona, M. (2017). Role of food neophilia in food market tourists' motivational construct: The case of La Boqueria in Barcelona, Spain. Journal of Travel \& Tourism Marketing, 34(4), 475-487. https://doi.org/10.1080/10548408.2016.1193100 


\section{Copyright 2022 Cognizant Communication Corporation}

Disegna, M., \& Osti, L. (2016). Tourists' expenditure behaviour: The influence of satisfaction and the dependence of spending categories. Tourism Economics, 22(1), 5-30. https://doi.org/10.5367/te.2014.0410

Du Rand, G. E. D., Heath, E., \& Alberts, N. (2008). The role of local and regional food in destination marketing. Journal of Travel \& Tourism Marketing, 14(3-4), 97-112. https://doi.org/10.1300/J073v14n03_06

Ellis, R. (2008). Maldives. Bradt Travel Guides.

Enzenbacher, D. J. (2019). Exploring the food tourism landscape and sustainable economic development goals in Dhofar Governorate, Oman: Maximising stakeholder benefits in the destination. British Food Journal, 122(6), 1897-1918. https://doi.org/10.1108/BFJ09-2018-0613

Etikan, I., Musa, S. A., \& Alkassim, R. S. (2016). Comparison of convenience sampling and purposive sampling. American Journal of Theoretical and Applied Statistics, 5(1), 1-4. https://doi.org/10.11648/j.ajtas.20160501.11

Everett, S., \& Aitchison, C. (2008). The role of food tourism in sustaining regional identity: A case study of Cornwall, South West England. Journal of Sustainable Tourism, 16, 150167. https://doi.org/10.2167/jost696.0

Fathimath, A., \& Milne, S. (2011). Marketing Maldives beyond "The sunny side of life": A role for food? E-Review of Tourism Research, 9(5), 134-163.

Getz, D. \& Robinson, R. N. S. (2014). 'Foodies' and Their TravelPreferences. Tourism Analysis 19(6), 659-672. https://doi-org/10.3727/108354214X14116690097693

Goolaup, S., \& Mossberg, L. (2017). Exploring the concept of extraordinary related to food tourists' nature-based experience. Scandinavian Journal of Hospitality and Tourism, 17(1), 27-43. https://doi.org/10.1080/15022250.2016.1218150

Goolaup, S., Solér, C., \& Nunkoo, R. (2018). Developing a Theory of Surprise from Travelers' Extraordinary Food Experiences. Journal of Travel Research, 57(2), 218-231. https://doi.org/10.1177/0047287517691154

Gram, M. (2010). Self-reporting vs. obseryation: Some cautionary examples from parent/child food shopping behaviour. International Journal of Consumer Studies, 34(4), 394-399. https://doi.org/10.1111/j.1470-6431.2010.00879.x

Green, J., \& Thorogood, N. (2018). Qualitative methods for health research. SAGE.

Guba, E. G. (1990). The paradigm dialog. SAGE.

Guba, E. G., \& Lincoln, Y. S. (1994). Competing paradigms in qualitative research. N. K. Denzin, \& Y. S. Lincoln (Eds.), Handbook of qualitative research (pp. 105 - 117). SAGE.

Hagsand, A. V., Roos af Hjelmsäter, E., Granhag, P. A., Fahlke, C., \& Söderpalm Gordh, A. (2017). Witnesses stumbling down memory lane: The effects of alcohol intoxication, retention interval, and repeated interviewing. Memory, 25(4), 531-543. https://doi.org/10.1080/09658211.2016.1191652

Hartmann, C., \& Siegrist, M. (2016). Becoming an insectivore: Results of an experiment. Food Quality and Preference, 51, 118-122. https://doi.org/10.1016/j.foodqual.2016.03.003

Hogendorn, J., \& Johnson, M. (1986). The shell money of the slave trade. Cambridge University Press.

Hjalager, A.-M., \& Corigliano, M. A. (2000). Food for tourists-Determinants of an image. International Journal of Tourism Research, 2(4), 281-293. https://doi.org/10.1002/1522-1970(200007/08)2:4<281::AID-JTR228>3.0.CO;2-Y

Hjalager, A.-M., \& Richards, G. (2002). Chapter 13: Still undigested: research issues in tourism and gastronomy. In Tourism \& Gastronomy (pp. 224-234). Taylor \& Francis. 


\section{Copyright 2022 Cognizant Communication Corporation}

Horng, J.-S., \& Tsai, C.-T. (2012). Culinary tourism strategic development: An Asia-Pacific perspective. International Journal of Tourism Research, 14(1), 40-55. https://doi.org/10.1002/jtr.834

Hussain, Z., Lema, J., \& Agrusa, J. (2012). enhancing the cultural tourism experience through gastronomy in the Maldives. Journal of Tourism Challenges \& Trends, 5(2), 71-83.

Izotovas, A., Vrij, A., Strömwall, L. A., \& Mann, S. (2020, October 1). Facilitating MemoryBased Lie Detection in Immediate and Delayed Interviewing: The Role of Sketch Mnemonic. Psichologija; Vilnius University Press. https://doi.org/10.15388/Psichol.2020.16

Johns, N., Edwards, J. S. A., \& Hartwell, H. (2011). Food neophobia and the adaption of new food products. Nutrition and Food Science, 41(3), 201-209. https://doi:10.1108/00346651111132475

Jordan, F. \& Gibson, H. (2004). Let your data do the talking: Researching the solotravel experiences of British and American women. In J. Phillimore \& L. Goodson (Eds.), Qualitative research in tourism: Ontologies, epistemologies and methodologies (pp. 215-235). Routledge.

Kim, J.-H. (2014). The antecedents of memorable tourism experiences: The development of a scale to measure the destination attributes associated with memorable experiences. Tourism Management, 44, 34-45. https://doi.org/10.1016/j.tourman.2014.02.007

Kim, Y. G., Eves, A., \& Scarles, C. (2009). Building a model of local food consumption on trips and holidays: A grounded theory approach. International Journal of Hospitality Management, 28(3), 423-431. https://doi.org/10.1016/j.ijhm.2008.11.005

Kim, Y. G., Suh, B. W., \& Eves, A. (2010). The relationships between food-related personality traits, satisfaction, and loyalty among visitors attending food events and festivals. International Journal of Hospitality Management, 29, 216-226. https://doi:10.1016/j.ijhm.2009.10.015

Kivela, J., \& Crotts, J. C. (2006). Tourism and gastronomy: Gastronomy's influence on how tourists experience a destination. Journal of Hospitality and Tourism Research, 30(3), 354-377. https://doi.org/10.1177//1096348006286797

Kivela, J. J., \& Crotts, J. C. (2009). Understanding travelers' experiences of gastronomy through etymology and narration. Journal of Hospitality and Tourism Research, 33(2), 161-192. https://doi.org/10.1177/1096348008329868

Knollenberg, W., Duffy, L. N., Kline, C., \& Kim, G. (2021). Creating competitive advantage for food tourism destinations through food and beverage experiences. Tourism Planning \& Development, 18(4), 379-397. https://doi.org/10.1080/21568316.2020.1798687

Larsen, S. (2007). Aspects of a psychology of the tourist experience. Scandinavian Journal of Hospitality and Tourism, 7(1), 7-18. https://doi.org/10.1080/15022250701226014

Lee, K.-H., \& Scott, N. (2015). Food tourism reviewed using the paradigm funnel approach. Journal of Culinary Science \& Technology, 13(2), 95-115. https://doi.org/10.1080/15428052.2014.952480

Lin, L., \& Mao, P.-C. (2015). Food for memories and culture - A content analysis study of food specialties and souvenirs. Journal of Hospitality and Tourism Management, 22, 19-29. https://doi.org/10.1016/j.jhtm.2014.12.001

Lupton, D. (1994). Food, memory and meaning: The symbolic and social nature of food events. Sociological Review, 42(4), 664-685. https://doi.org/10.1111/j.1467954X.1994.tb00105.x

MacCannell, D. (1999). The tourist: A new theory of the leisure class. University of California Press. 


\section{Copyright 2022 Cognizant Communication Corporation}

Mak, A. H. N., Lumbers, M., Eves, A., \& Chang, R. C. Y. (2013). An application of the repertory grid method and generalised Procrustes analysis to investigate the motivational factors of tourist food consumption. International Journal of Hospitality Management, 35, 327-338. https://doi.org/10.1016/j.ijhm.2013.07.007

Mangi, H. O., \& Urassa, J. K. (2017). Local versus imported food: opportunities and constraints for Tanzanian hotels. Journal of Gastronomy and Tourism, 2(4), 247-258. https://doi-org/10.3727/216929717X15046207899401

Mason, M. (2010). Sample size and saturation in $\mathrm{PhD}$ studies using qualitative interview. Qualitative Social Research, 11(3), No. 3. https://doi.org/10.17169/fqs-11.3.1428

Mekoth, N., \& Thomson, A. R. (2018). Food preferences and culture: The influence of nationality and religion among tourists visiting Goa. Tourism Culture \& Communication, 18(3), 191-204. https://doi.org/10.3727/109830418X15319363084472

Menozzi, D., Sogari, G., Veneziani, M., Simoni, E., \& Mora, C. (2017). Eating novel foods: An application of the theory of planned behaviour to predict the consumption of an insect-based product. Food Quality and Preference, 59, 27-34.

https://doi.org/10.1016/j.foodqual.2017.02.001

Ministry of Tourism (2019). Registered facilities. Retrieved from //www.tourism.gov.mv/registered-facilities/

Morgan, M., \& Xu, F. (2009). Student travel experiences: Memories and dreams. Journal of Hospitality Marketing \& Management, 18, 216-236. https://doiorg./10.1080/19368620802591967

National Bureau of Statistics (2020). Statistical yearbook 2020. http://statisticsmaldives.gov.mv/yearbook/2020/

Neill, L., Johnston, C., \& Losekoot, E. (2016). New ways of gazing: The refractive gaze. International Journal of Tourism Anthropology, 5(1-2), 138-151. https://doi.org/10.1504/IJTA.2016.076852

Neuman, W. L. (2014). Social research methods: Qualitative and quantitative approaches. Pearson.

Obrist, M., Comber, R., Subramanian, S., Piqueras-Fiszman, B., Velasco, C., \& Spence, C. (2014). Temporal, affective, and embodied characteristics of taste experiences: A framework for design. Proceedings of the SIGCHI Conference on Human Factors in Computing Systems, 2853-2862. https://doi.org/10.1145/2556288.2557007

Okumus, B. (2020). Food tourism research: A perspective article. Tourism Review, 76(1), 38 42. https://doi.org/10.1108/TR-11-2019-0450

Palmer, C., \& Andrews, H. (2019). Tourism and embodiment. Routledge.

Pan, S., \& Ryan, C. (2009). Tourism sense-making: The role of the senses and travel journalism. Journal of Travel \& Tourism Marketing, 26(7), 625-639. https://doi.org/10.1080/10548400903276897

Pine, B. J., \& Gilmore, J. H. (1999). The experience economy: work is theatre \& every business a stage. Harvard Business Press.

Prince, M. \& Basil, M. (2011). Use of photography and video in observational research. Qualitative Market Research: An International Journal, 3, 246-257. https://doi.org/10.1108/13522751111137488

Quan, S., \& Wang, N. (2004). Towards a structural model of the tourist experience: an illustration from food experiences in tourism. Tourism Management, 25(3), 297-305. https://doi.org/10.1016/S0261-5177(03)00130-4

Rahman, M. S., Zaman, M. H., Hassan, H., \& Wei, C. C. (2018). Tourist's preferences in selection of local food: Perception and behavior embedded model. Tourism Review, 73(1), 111-132. https://doi.org/10.1108/TR-04-2017-0079 


\section{Copyright 2022 Cognizant Communication Corporation}

Raskin, J. D. (2008). The evolution of constructivism. Journal Of Constructivist Psychology, 21(1), 1-24. https://doi.org/10.1080/10720530701734331

Richards, G. (2002). Gastronomy: an essential ingredient in tourism production and consumption? In A-M. Hjalager \& G. Richards (Eds.), Tourism and gastronomy (pp. 3-20). Taylor \& Francis.

Richards, V., Pritchard, A., \& Morgan, N. (2010). (Re)Envisioning tourism and visual impairment. Annals of Tourism Research, 37(4), 1097-1116. https://doi.org/10.1016/j.annals.2010.04.011

Ritchie, J. R. B., \& Crouch, G. I. (2003). The competitive destination: A sustainable tourism perspective. $\mathrm{CABI}$.

Romero-Frias, X. (1999). Folk tales of the Maldives. NIAS Press.

Romero-Frias, X. (2017). Eating on the islands. Retrieved from http://himalmag.com/eatingon-the-islands/?currentPage=all

Sánchez-Cañizares, S. M., \& López-Guzmán, T. (2012). Gastronomy as a tourism resource: Profile of the culinary tourist. Current Issues in Tourism, 15(3), 229-245. https://doi.org/10.1080/13683500.2011.589895

Saumure, K., \& Given, L. M. (2008). Convenience Sample. In L. Given (Ed.), The SAGE encyclopedia of qualitative research methods (p. 125). SAGE. https://doi.org/10.4135/9781412963909

Shakeela, A. (2000). Classical Maldivian cuisine. Impression.

Schänzel, H. A., \& Lynch, P. A. (2016). Family perspectives on social hospitality dimensions while on holiday. Tourist Studies, 16(2), 133-150. https://doi:10.1177/1468797615594742

Sharpley, R., \& Sundaram, P. (2005). Tourism: a sacred journey? The case of Ashram tourism, India. International Journal of Tourism Research, 7(3), 161-171. https://doi:10.1002/jtr.522

Smith, V. L. (1979). Women the taste-makers in tourism. Annals of Tourism Research, 6(1), 49-60. https://doi.org/10.1016/0160-7383(79)90094-X

Son, A., \& Pearce, P. (2005). Multi-faceted image assessment. Journal of Travel \& Tourism Marketing, 18(4), 21-35. https://doi.org/10.1300/J073v18n04_02

Sthapit, E. (2017). Exploring tourists' memorable food experiences: A study of visitors to Santa's official hometown. Anatolia, 28(3), 404-421. https://doi.org/10.1080/13032917.2017.1328607

Stojanov, R., Duží, B., Kelman, I., Němec, D., \& Procházka, D. (2017). Local perceptions of climate change impacts and migration patterns in Malé, Maldives. The Geographical Journat, 183(4), 370-385. https://doi.org/10.1111/geoj.12177

Sutton, D. E. (2001). Remembrance of repasts: An anthropology of food and memory. Berg. Techera, E., \& Cannell-Lunn, M. (2019). A review of environmental law in Maldives with respect to conservation, biodiversity, fisheries and tourism. Asia Pacific Journal of Environmental Law, 22(2), 228-256. https://doi.org/10.4337/apjel.2019.02.03

Tinson, J., Nancarrow, C., \& Brace, I. (2008). Purchase decision making and the increasing significance of family types. Journal of Consumer Marketing, 25(1), 45-56. https://doi.org/10.1108/07363760810845408

Torres, R. (2002). Toward a better understanding of tourism and agriculture linkages in the Yucatan: Tourist food consumption and preferences. Tourism Geographies, 4(3), 282306. https://doi.org/10.1080/14616680210147436

Tuckey, M. R., \& Brewer, N. (2003). The influence of schemas, stimulus ambiguity, and interview schedule on eyewitness memory over time. Journal of Experimental Psychology: Applied, 9(2), 101-118. https://doi.org/10.1037/1076-898X.9.2.101 


\section{Copyright 2022 Cognizant Communication Corporation}

Uriely, N. (2005). The tourist experience-Conceptual developments. Annals Of Tourism Research, 32(1), 199-216. https://doi.org/10.1016/j.annals.2004.07.008

Urry, J. (2002). The tourist gaze. SAGE.

Viljoen, A., Kruger, M., \& Saayman, M. (2018). The art of tastings: Enhancing the arts festival experience. International Journal of Event and Festival Management. https://doi.org/10.1108/IJEFM-03-2018-0023

Volo, S. (2009). Conceptualizing experience: A tourist based approach. Journal of Hospitality Marketing \& Management, 18(2-3), 111-126. https://doi.org/10.1080/19368620802590134

Wang, S., Holloway, B. B., Beatty, S. E., \& Hill, W. W. (2007). Adolescent influence in family purchase decisions: An update and cross-national extension. Journal of Business Research, 60(11), 1117-1124. https://doi.org/10.1016/j.jbusres.2007.04.004

Yin, R. K. (2014). Case study research: Design and methods $\left(5^{\text {th }}\right.$ ed). SAGE? 